\title{
Review Article \\ Chitra Banerjee Divakaruni's The Forest of Enchantments: A Saga of Duty, Betrayal, Integrity and Honour
}

\author{
Sukanya Saha \\ Assistant Professor Department of English and Foreign Languages, SRM Institute of \\ Science and Technology, Kattankulathur campus, Chennai, Tamilnadu. \\ sukanyap@srmist.edu.in
}

Book Name: The Forest of Enchantments

Genre: Fiction

Author: Chitra Banerjee Divakaruni

Publisher: HarperCollins Publishers India

Year of Publication: 2019

Book Image:

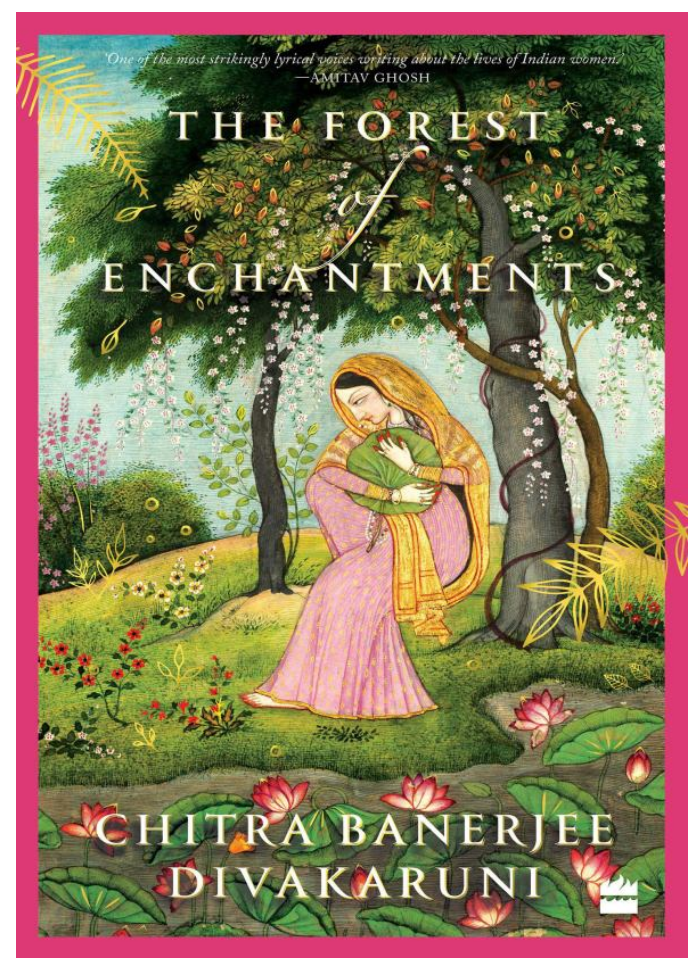

Total Pages: 359

...not all women are weak and helpless like you think. (111)

(c) AesthetixMS 2019. This Open Access article is published under a Creative Commons Attribution Non-Commercial 4.0 International License (http://creativecommons.org/licenses/by-nc/4.o/), which permits non-commercial re-use, distribution, and reproduction in any medium, provided the original work is properly cited. For citation use the DOI. For commercial re-use, please contact editor@rupkatha.com. 
Chitra Banerjee Divakaruni weaves the fabric of her Sitayan with strings essentially pulled out from Sage Valmiki's Ramayan. She deftly accomplishes the dual task of adhering to the originality of this ancient text and introducing a renewed perception through which this epic could be reconsidered as base for moral standings. The images, characters, facts, and ideals of Ramayan are deep-seated in Indian consciousness and Banerjee infuses with it the enchanting quality of her storytelling to recreate them from Sita's perspective. Her motifs are familiar yet molded to reverberate her stance. She adopted a novel approach anchored firmly in values inculcated through Ramayan. Her inversions often fringe on condemning lopsided judgements about moralities, yet she consciously eschews the prospects of remodeling the venerable narrative which the reader, yearning for happy endings, would have been thrilled to find though. Banerjee often stimulates a penetrating wish, a fond thought, about inverse turn of events during her narration. A sincere urge to experience the transformed fates of characters in Ramayan grows increasingly strong while reading The Forest of Enchantments.

The author conducted an extensive research with four different versions of Ramayan, Valmiki Ramayan, Adbhuta Ramayan, Kamba Ramayan and Bengali Krittibasi Ramayan (viii). She explored folk songs about Sita to portray her in most convincing way possible. Banerjee's version of Sita is also backed by her strong urge to represent Sita, who is idolized as 'good and meek, and long-suffering, bearing her misfortunes with silent stoicism' (viii) in a diction which would alter her archetypical image of idealistic and coy Indian woman. Sita of Ramayan must be a goddess but Banerjee's Sita is a human, a one who is relatable. Sita's contemporary rendition is focal in this novel. She is capable of being smitten, angry, confused, afraid, or heartbroken. Banerjee confines the portrayal of her Sita within the dictates of the epic and at the same time lets her fancy take flight in endowing Sita with an unmatched intellect, martial art skills, penchant for latest fashion, and ability to express intimate desires sans inhibitions. Banerjee's Sita mirrors contemporary woman in every bit as far as she could exercise control over her creation. Although Banerjee goes overboard at times in this process, but the incredulousness in her account is miniscule before the exhaustive portrayal of her heroine as a rebel, warrior and trailblazer. Banerjee, indeed, took up a humongous project where she sets out to redefine the divine as human and recount a tale about a woman who is glorified beyond measures, yet is speculated over with shallow certitudes.

Banerjee stays honest to the Ramayan despite a constant calling of impassioned bent for Sita and other women from this epic who Banerjee thinks deserve retelling. The linearity of plot underlines Sita's inevitability as a narrator, where her perspective enlivens the sketches of several women who were pushed towards margins. Sita assumes the responsibility of bringing those women to fore who contributed their bit in making Ramayan 'the cosmic drama of good and evil' (266). She holds Sita above commonplace in projecting her courage and endurance against all odds and her divine forgiveness. Sita voices all those women who have never been thought about extensively, namely, Sunaina, Urmila, Kaikeyi, Surpanakha, Ahalya, Shabari, Tara, Mandodari, or Sarama, 'Write our story, too. For always we've been pushed into corners, trivialized, misunderstood, blamed, forgotten-or maligned and used as cautionary tales.' (4)

Sita elaborates Koushalya's agony about husband's ignorance and failing to retain son's attention. Her accounts of Kaikeyi and Surpanakha portray them in different light against the backdrop of widespread derogatory opinions about them. Both are endowed with humanly emotions yet are hugely misconstrued in articulating what their hearts desired and mind commanded. The hasty and biased judgments about their conduct certainly ensued from their creator's bent of mind and reader's ease in grasp of the narrative. Mandodari's womanly instincts are no match against the towering and overwhelming presence of her husband, Ravana in 
Ramayan. Sita highlights Mandodari substantially by associating her with the truth of her own birth. Urmila's character perhaps would draw maximum sympathy. A young girl whose dreams of a prosperous household and loving husband shatter when she was deliberately ignored and abandoned by Lakshman for fourteen long years, at prime of her youth. Her question to Sita is heart-rending, 'Ram took you with him. Why then did Lakshman refuse to take me? Was I so unworthy?' (281) Her vulnerability might read irksome to the contemporary readers, but Urmila's resilience would endear her too. Her life of fourteen years might be conveniently omitted from the pages of Ramayan, but Sitayan answers for that void. She is given her due reverence as Sita's confidante and a dutiful wife who battled her own hardships.

Banerjee's delineation of Sita's psyche is a wonderful amalgamation of ecstasy, fancy, love, passion, remorse, despondency, frustration, and a host of emotions, which infuse vitality in this whole tapestry. She brings Sita alive as an epitome of courage and most importantly, self-respect. The insights which Banerjee provides etch indelibly. These infiltrate reader's moral constitution firmly established by unquestioning faith in Ramayan's sacred entity for centuries. Sita is an icon of dignity which for Banerjee is the fulcrum of a woman's existential dilemma. She endures persistent attacks over her integrity and ultimately refuses to surrender to them in a fashion which is characteristic to divine. The voices of the narrator and the protagonist often merge as Sita's story exemplifies a battle of wills where she epitomizes women who struggle to gain ground in a world which unjustly inclines towards men. As her fortitude reaches to its culmination, she chose to renounce this world with dignity which unjustly subjected her to dolors. Sita's maxims strike a chord somewhere deep within, soaked in veracity of life, 'How innocent we'd been, thinking that if only we willed something hard enough, it would come true.' (116), 'How ironic that the joyous times we'd like to hold on to are the most fleeting, while the saddest ones clutch at us, refusing to let go.'(247) 'But perhaps guilt keeps us from seeing things that are otherwise as clear as a cloudless sky.' (343)

The domineering first person narration eliminates several anecdotes indispensable to Ramayan, for instance, Ram's establishing alliance with Sugreev after defeating Bali, whose monkey battalions play a major role in the epic war. Banerjee thus retains the focus essentially over Sita who emerges as an embodiment of strength and solidarity during her ordeal in Ravan's captivity. Banerjee vetted the details from Ramayan adding what she deemed integral to Sitayan. She elaborately and exquisitely details Sita's life from the beginning: being found wrapped in strange fabric; her childhood in Mithila with Janak and Sunaina, a doted father, a perceptive mother and a loving sister, Urmila; her sensibility and knowledge of foliage and herbs; training and mastery in martial arts; marriage and youthful conjugal love; adapting to a new household; days in the wild; self-restraint during captivity; dignity in embracing fire; reigning as a beloved queen; heartbreak in banishment; maternal joys; and an awe-inspiring merger into the mother earth.

Despite Ramayan being a common lore in Indian households, Sita's portrayal by Banerjee appeals being driven with joy, intensity, and sincerity. Banerjee is honest in her intent of making her Sitayan independent of overwhelming influences of Ramayan. She also adds a new dimension to it by making it 'a meditation on the nature of love' (ix). She exclaims, 'Ah, love! Why had Vidhanta made its nature so complex?' (204). Banerjee makes it a point to underline the predicaments love caused during decisive moments. Prior to her account, the prospect of Ramayan as a 'tragic love story' was probably unthought of. The glorification of Lord Rama in Ramayan overshadowed Sita partially and all those women completely who merely existed and were never sincerely acknowledged for their roles. 
The foundation of Sitayan is laid on unraveling 'the complexity of the female existence' (257). The custom and codes, obligatory for women are harsher and more rigid than they are for their male counterparts. Banerjee is quite articulate about it, '...it was jealousy of the freedom given to men to go wherever they wanted in the wide world.' (110) Her account adopts a tone of protest when she flings rhetorical questions that would transformed the course of Sita's lives in Ramayan, 'what of his wife? Would he ever consider her to be as important as his dharma?' (40) 'Was a man's pride more important than the truth?' (46), 'In my kingdom every man will have a voice, no matter how humble he is...I wanted to ask, what about the women?' (97), '...he'd banished me and his babies, all three of us equally innocent, because he believed that was his duty to his people. But weren't we his people, too? Didn't he have a duty to us?' (320)

Banerjee gives vent to her exasperations through Sita's wisdom and often, outbursts, 'No blame should ever attach to a king, for then how can he pronounce judgement on another?' (66), 'People always talk. Should an elephant turn around and runaway because dogs are barking?' (316) A woman's premonitions are her gift. Sita's mother Sunaina's fear proves true, '...things might change, especially when it's time for Dashrath to announce his heir.' (47) Sita senses the imminent and her remarks conjure awe about future, 'This happens to me sometimes. It's as though some inner voice guides me.' (33), 'But who was it I spoke to with such loathing? And who was it that responded with such dark elation?' (41) 'I said goodbye to her in the ashram, that I'd only see her again on the last day of my life.' (351)

Banerjee exploits reader's knowledge of Ramayan to her advantage. The dramatic quality of her narration makes the book unputdownable, adding to anxiety in the informed reader, 'Ah, the stupid masses. They'll soon be dancing to a different tune' (102) '...I will choose the revenge that will hurt them the most' (153). Sita's apprehensions raise a pang, 'The deer appeared soon after that.' (155), 'Mahakal awakes. Let the deaths begin.' (215), 'I didn't know that, for me, a greater sorrow was about to begin.' (237), 'What was it that worried Vasista at this auspicious moment? (299)

The author constantly strives for a balance between benevolence and malevolence; love and wicked desire; magnanimity and unbridled pride; personal and worldly, while evolving each character. Sita's objective judgment of a character strengthens Banerjee's portrayal of her as a righteous woman. In her most dejected state, she acknowledges Ravana's grandeur, 'I'd wanted to believe that he was a tyrant, but I could see that he was dearly loved. And he was a good leader, equally gracious to all, acknowledging greetings whether they were offered by the aristocrat or the more humble citizens.' (174), '...Ravan had been a mighty sovereign, a much loved hero to his people, and a sincere devotee of Shiva' (231) Sita relates Ravana's share of life's anguishes where he bore humiliation, practiced extreme penance and became superior to Gods in power, 'What use was life if I had to live it as powerless as a worm?' (198) Ravana wanted to avenge his sister, yet he fell prey to pride and arrogance. Although Sita hated him but she is never bitter about him.

One would wonder about Sita's panegyrics about her conscientious, justice-loving, 'perfect' husband Ram while composing Sitayan. Her unfazed love and devotion to Ram is something which Banerjee kept essentially intact, perhaps this helped her add intensity to Sita's ethereal piety. The vortex of her unswerving devotion to a husband who is prompt in abandoning her, sweeps with it a plethora of questions raised about the limit of a woman's tolerability. Ironically, this ultimately leads her towards the pyre where she is asked to sacrifice her selfesteem, her identity to earn the coveted status of 'a socially approved' wife. Her plight is a sharp stab which carves lasting marks mocking her forgiving and sacrificial impulses that drive her 
towards her own doom. The question rearing its head here is about a woman being asked about the hallmark of chastity by conducting self-immolation.

Sita's life oscillates between two extremes, royalty and wilderness, emanating many-hued emotions and impulses. Sitayan is emergence of an independent voice, unabashed of social inhibitions, voicing a modest protest which never turns into a tirade. Banerjee chose her parameters and drew her margins in a calculated manner. Sita is an emancipated woman who is moored to filial commitments. Her plight in this mortal plane has left many questions unresolved and would serve as an intense point of contention.

Dr. Sukanya Saha is working as an assistant professor in the department of English and Foreign Languages at SRM Institute of Science and Technology, Kattankulathur campus, Chennai, Tamilnadu. She has been engaged in teaching English to B.Tech. Engineering students and English literature to B.A. and M.A. Literature students for more than seven years now. Her research interests include Stylistic analysis of literary texts, Contemporary World Literature in English, Semiotics, and Psychoanalysis. 